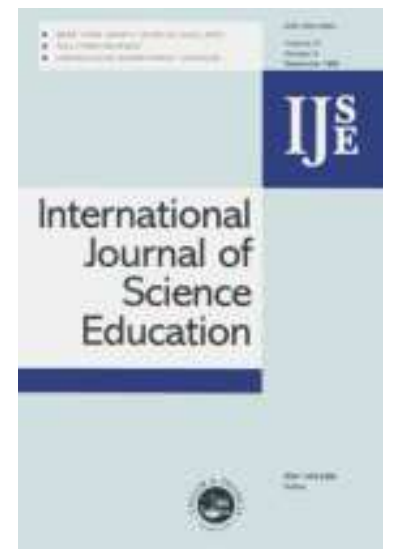

\title{
Narrative inquiry for science education: teachers' repertoire-making in the case of environmental curriculum
}

\begin{tabular}{|r|l|}
\hline Journal: & International Journal of Science Education \\
\hline Manuscript ID: & TSED-2010-0049 \\
\hline Manuscript Type: & Research Paper \\
\hline Keywords: & $\begin{array}{l}\text { environmental education, nature of science, qualitative research, } \\
\text { teacher knowledge, curriculum }\end{array}$ \\
\hline Keywords (user): & \\
\hline
\end{tabular}

\section{S) ScholaroNE}


Abstract

This paper considers how the school science curriculum can be conceptualised in order to address the contingent and complex nature of environmental and sustainability-related knowledge and understanding. A special concern lies in the development of research perspectives and tools for investigating ways in which teachers are faced with complex and various situations in the sense-making of science-related issues, and subsequent pedagogic issues. Based on an empirical examination of Korean teachers' sense-making of their curricular practice, the paper develops a narrative approach to teachers' perspectives and knowledge by considering the value of stories as sense-making tools for reflective questioning of what is worth teaching, how and why. By employing the idea of 'repertoire', the study regards teachers' stories about their environment-related personal and teaching experiences as offering angles with which to understand teachers' motivation and reflection in curricular development and implementation. Furthermore, three empirical cases present ways in which the nature of knowledge and understanding is recognised and potentially integrated into pedagogies through teachers' narratives. Finally, the paper argues for the need to reconsider the role of the science teacher in addressing environmental and sustainability-related issues, in ways that facilitate teachers' reflexive interpretation of meanings in cultural texts and the construction of pedagogic text.

Keywords: environmental and sustainability issues; narrative inquiry; science curriculum; teacher knowledge; repertoire. 


\section{Challenges for teachers in addressing environmental issues}

Since environmental issues became part of the school curriculum, much attention has been drawn to beliefs, concepts, values, attitudes and reasoning (Reid \& Scott, 2006, p.581), reflecting the dominance of a concept-based model of the curriculum and teacher knowledge. In fact, a broad range of research in this field catalogues and differentiates teachers' and pupils' diverse understanding of the environment or environmental issues (e.g. Agelidou \& Flogaitis, 2003; Loughland, Reid, \& Petocz, 2002; Shepardson, Niyogi, Choi, \& Charusombat, 2009, to name but a few). While scientific knowledge is still given dominance in traditional environmental education, the legitimacy of science has been critically examined in many disciplinary areas (Irwin, 1995; Kuhn, 1962; Midgley, 1992; Nowotny, Scott, \& Gibbons, 2000), including science education (Carter, 2008; Colucci-Gray, 2006; XXXX, 2010 in press). The discourses of science in relation to environmental and sustainability issues have shifted to an epistemological level at least, from the point of view that scientific knowledge possesses an absolute authority in providing diagnoses and solutions to environmental issues: instead, it is often argued that science should take the role of a 'mediator' through gearing the nature of scientific work and endeavour toward reflexivity throughout all the processes in which it is shaped. Such topics include climate change, nano-technology and stem-cell research, all of which give rise to considerable degrees of uncertainty and unpredictability, and to social and ethical issues.

Yet, the discourse-practice gap should be addressed by examining actual teaching and learning contexts rather than assuming the linear relationship between them. In fact, studies of socially controversial scientific issues have offered various pedagogical models, as well as discovering problems in them (Jiménez-Alexiandre \& 
Pereiro-Muñoz, 2002; Kolstø 2001; Oulton, Dillon, \& Grace, 2004; Zeidler, Sadler, Simmons, \& Howes, 2005). One strand of findings relates to teachers' lack of confidence with regard to the merit of dealing with issues for science learning (Bryce, 2004), the other being teachers' dilemmas between their own views and their role as facilitator of pupil's learning (Cotton, 2006; Michael, Grinyer, \& Turner, 1997; XXXX 2009). Yet others take a more radical approach by questioning the dichotomy between (Western) science and other forms of knowledge (Gough, 2002; Weinstein, 2006). Weinstein criticises that stress lain upon the nature of science in recent science education literature that often encourages pupils' learning about real-world contexts is still based on the assumption of science being a unitary practice, therefore a contestation of knowledge claims is caused by external factors (Weinstein, 2006).

While acknowledging that there is a critical difference in the viewpoints among researchers in defining the boundary between 'science' and social processes, this paper proceeds from the assumption that educational concepts such as pedagogy, curriculum, teaching and learning are not unrelated to the question of what is knowledge(able) and understanding for addressing environmental and sustainabilityrelated issues in science education, and that it is the task of educational researchers to develop various pedagogic models and curricular approaches that take into account the very problematic nature of such a knowledge construction process. This study maintains that there is a need for either expanding or refocusing ways of understanding teaching practice as something that is more than that simply constituted by teachers' conceptions and knowledge, by taking into account the teacher's personal experiences and reflections that form and transform a teacher's thinking (Corney \& Reid, 2007). Against this backdrop, the paper develops a narrative inquiry into 
teachers' environment-related knowledge and curricular practice, in the context of Korean secondary school education.

\section{Narrative inquiry for interrogating teachers' thinking and science education}

Narrative researchers consider curricular stories as consisting of pedagogical content knowledge that is shaped through a narrative way of knowing. In this view, it is believed that teaching is understood basically as the making of meaning, like "writing a story", and that "the understanding of teaching is like arriving at an interpretation of a story" (Gudmundsdottir, 1991, p.217). Carter (1993) makes a similar point in making a case for the study of narrative structures of teachers' curricular knowledge in ways that highlight the interpretive and inventive processes involved in teaching. Overall, this approach to teachers' knowledge is grounded in the belief that teaching is based on a teacher's personal resources, values and life experience (Elbaz-Luwisch, 2007). Informed by the narrative approaches to teachers' curriculum, however my inquiry started with the critical reflection that there has been less emphasis on the 'sources' of curricular stories (Hart \& Nolan, 1999), including different social and cultural sites that are related to the construction of meaning with respect to what constitutes an issue and what should be addressed through education.

For this reason, I am particularly interested in how teachers' curricular stories can be conceptualised in terms of narrative form or understood via narratives, by taking the definition of narrative as being "interwoven with a broader cultural set of fundamental discursive orders that determine who tells which story, when and where, why and to whom" (Brockmeier \& Harré, 2001, pp.41-42). Narratives are not 'descriptive' nor represent objective truth, as with realism, or objectivist interpretivism, and the form, genre or discourse type of narrative is not a pre-given 
category, but is 'constructed', e.g. by cultural models or repertoires (Bruner, 1991). In this sense, narratives are seen less as an ontological entity, and more as discursive practices that shape rules and structures of knowledge, action and experience (Chase, 2005; Mishler, 1986; Riessman, 2003). The proposition about narrative inquiry narrative as discourse, as constructing social meanings - enables this study to go beyond simple analytic approaches to teachers' stories, such as thematic or content analysis that yields some types and categories in teachers' thinking such as belief, conception or knowledge. While understanding the diversity or features inherent in the category is still a useful way of describing how things are, it does not necessarily conceptualise teachers' stories as performing social actions within the specific sociocultural milieu. Instead, my concerns lie with the question of where the story is embedded and where the meanings are possibly and plausibly located, in the hope that "good stories rattle commonplace assumptions and disturb taken-for-granted beliefs" in or about education (Barone, 1997, p.223; Hart, 2008). In conceptualising curriculum-making as teachers' story-telling and a meaning-making process, I maintain that curriculum stories represent more than the predetermined body of subject content, but rather, social interactions between wider socio-cultural processes and school education, and ways in which culturally prevailing or dominant forms of narratives are operating, 'translated' into pedagogical modes, or even challenged.

This view on narrative pertains to questions of relationships between environmentally-focused narratives and the role of science education. Indeed, global environmental issues such as climate change have become popular stories (e.g. Al Gore's 2006 film, An Inconvenient Truth), and the role and authoritativeness of a science discourse appear crucial to making stories appear more powerful in discussion and debate about the 'truth' and 'solutions' (e.g. The Intergovernmental Panel on 
Climate Change, Solomon et al., 2007). Whilst such environmentally-focused narratives may provide strong societal momentum for institutionalising and legitimatising the role of education, and promoting educational approaches to environmental concerns through international and national policy interventions, such as the UN Decade for Education for Sustainable Development (2005-2014), they are not without their problems. In particular, behaviourist and instrumentalist discourses on the role of education have become the very predicament for educationalists whose concerns are not so much about doing as being 'told' to do (e.g. by the media, science or even educational policies), by obviating opportunities to pursue and articulate critical 'readings' of those narratives and discourses from the different, competing perspectives expected of effective pedagogical situations, practices and scenarios ${ }^{\mathrm{i}}$.

From the discussion so far, a science educator may feel motivated to face the task of reconsidering previous pedagogical approaches in order to facilitate learning that critically examines the usefulness and constraints of the 'truth' and 'solutions', and to engage more fully with the issues of uncertainty and to risk the possibility of what the scientific discourse of environmental and sustainability issues entails. Indeed, when the inquirer's pedagogical accent shifts from telling and finding the truth in such a way, an emerging issue is, 'What are other and new ways of pursuing pedagogical and educational truth?'. Studies on teacher thinking have so far focused more on the exploration of multiple interpretations of the very notion of nature and the environment (Cook, 2008; Gough, 1999; Payne, 2005), whereas there is less attention paid to an empirical investigation into the teachers' curriculum-making process, apart from some findings from teacher activism (Barret, 2008; Whitehouse, 2001). 
In order to contribute to further discussion in this area, this study tries to discover ways of investigating what constitutes environmental knowledge and how pedagogical approaches are contested and subject to changes depending on particular environmental issues. Since interdisciplinary approaches often require subject teachers to make changes in the teacher's 'script', it is of importance to explore the signifying processes that involve the construction of meanings concerning the environment in an educational or pedagogical sense, that is, by asking how teachers come to construct pedagogically meaningful stories. Teachers' stories about environmental education, if well told, are, then, the ones that create new meanings for themselves and society.

\section{Interview method: What comes before the curriculum?}

The study indicated here is derived from my doctoral thesis, which developed a narrative inquiry into Korean teachers' perspectives and knowledge in environmental education (XXXX 2008). Whilst I have already presented some of the research results elsewhere, with a focus on the value of teacher rhetoric in conceptualising professionalism (XXXX 2009), the focus of this paper lies within the specific contents of curricular topics in view of the sense-making process. An empirical study was designed to investigate the curriculum through teachers' own accounts, and to understand how curricular stories are constructed by weaving together the multiple elements of: 'environmental', 'topical', 'issues' and 'information' in a particular cultural context, and therefore to explore a narrative way that indicates how teachers (individually or collectively) take up cultural resources, and plan and implement their curriculum. 
The conversation method (Elbaz, 1991; Hart, 1996) helped teachers and the researcher work together to construct and re-tell meanings of 'environment-related experiences'. In the interview, my role was to encourage teachers' thinking processes so that they could gradually begin to search for some aspects of meaningful experiences, incidents and memories, backwards and forwards, and to make links between thoughts and experiences in ways that shaped the meanings of environmental education. I often asked questions and added comments regarding their views, in a polite way, hoping that they would begin to engage in reflective thinking. In so doing, my intention was to engage in more collaborative meaning-making processes. Our conversation touched upon various elements of their life stories in that interviews were driven by naturally occurring talk and discussion, encompassing teachers' life experiences and self-awareness of their personal and professional growth, rather than by particular concepts and perspectives. The primary interest was that life stories orient research towards a 'person-centred view' (Atkinson, 2002), in the sense that it goes deep into people's consciousness; in this study, how a teacher's personal meanings of environment-related experiences are integrated into their thoughts and beliefs about self: as a person, a teacher, an environmentalist, a citizen, a parent, etc. 'Significant life experiences' (SLE) ${ }^{\text {ii }}$ were then noted as teachers recalled some critical incidents and special memories, not only in terms of their influences on teachers' environmental views and activism, but also concerning building (no matter how tentative) coherent meanings of personal histories by making connections between the narrative threads of past-present-future.

Interviews with eleven teachers including five science, two humanities and four environment teachers - teachers who teach optional environment subjects, elicited various tales of environmental issues which are usually 'topical', but in fact 
composed of personal, cultural, historical and political constructions (see teacher profiles in Table 1). In the doctoral thesis, I reconstructed these tales in terms of key cultural events to indicate that science stories should be understood from the perspective of culture as providing interpretive repertoires, therefore impinging on the way in which perceptions and knowledge about 'environment' are constructed. For example, teachers' conception about curriculum that addresses health issues was closely related to the current 'well-being' (used in the English vernacular) fever in Korea. 'Well-being' has been the dominant idiom in recent discourses surrounding new life styles and consumerism and has become a culture pursuing a healthy life beyond materialistic values. The 'well-being' phenomenon in fact includes different kinds of discourse and various forms of action, from green marketing that promotes environmentally friendly products or even 'greenwashing', (lit. green whitewashing) which disingenuously does so, to personal pursuit of spiritual and post-materialistic life styles, and to ethical consumerism for tackling global environmental injustice, such as 'Fair Trade'. Some teachers expressed concerns during interviews about market-driven health and environmental trends and strategies. In this way, current environmental issues were regarded as conveying frames of reference in which meanings of 'pro-environmental' 'action' are preconceived, being arguably central concepts that comprise the objective of education. This indicates that actual teaching and learning situations involve attempts to comprehend and render explicit the meanings amongst the messages that such meta-narratives deliver. For example, for June, a middle-school science teacher, education should engage pupils in seeing the truth beyond superficial understanding. Her teaching approach, therefore, has been an attempt to combine pupils' scientific inquiry with critical literacy: 
"In my view, environmental education is not about teaching specific topics, but about attitudes, taking sceptical attitudes towards things addressed in the newspapers. For example, I consider analysis of advertisements very effective for pupils' learning. 'Well-being' is becoming a popular trend today, so when an advertisement says, "This is good for health", then people might just buy it without suspicion; but pupils should be able to question, for example, "Why is it good?" or "How is it pro-environmental?". I think this is of paramount importance to a scientific attitude and to environmental education. We should have a sceptical attitude towards everything, and not believe (that) what advertisements say, is things as they really are. For example, when teaching about food and digestion in the biology curriculum, pupils are encouraged to analyse the ingredients of 'well-being' milk. They are shocked when they find out that it contains excessive sugars, and is therefore even less healthy than normal milk. In this way, they realise there are myths hidden in advertisements, and they find it very exciting. This is what my teaching aims for: to encourage pupils to question, and if things are not trustworthy, then go on to ask, 'How can we investigate the truth'?"

The teacher's sense of confidence and persuasiveness in the enactment of an environmental curriculum is observed here. Yet for most teachers, the challenge was the lack of institutional support in the preparation of the curriculum, that is, everything is up to the individual teacher's efforts. The individualised practice of environmental education is suggested in teachers prioritising particular curricular topics, based on different pedagogical purposes and contexts of action and experience. For example, Han's (- being a high school, earth science teacher -) 'alternative energy' teaching cannot be fully understood without the stories about her involvement 
in NGO activities; but commonalities are found: curriculum stories about environmental education highlight a teacher's own efforts and learning in developing or expanding their curricular repertories. The view of a teacher as a curriculum-maker sheds light on teachers' preferred teaching approaches or subject matter and their recognition of the 'teachable moment', but crucially also on the manner in which the order of discourses are explicated, or endorsed by themselves, other teachers and pupils. Notably, the contemporariness and locality of environmental and sustainability-related issues often inform the current 'hot' topics to be taught. In many cases, teachers addressed how they selected and utilised the media reports on sciencerelated controversial issues, which suggests that multiple social meaning-making systems and processes that constitute the realities of 'environmental issues' are key mediators of curricular practice.

[Please insert Table 1 here.]

\section{Conceptualising repertoire: How teachers construct pedagogically meaningful} stories

All teachers interviewed often addressed their particular interests and concerns related to the environment, although only part of them were implemented through the actual teaching. In fact, the development of new repertoires seemed to be related to teachers' expertise and teaching experiences. It is through such understanding that the notion of 'repertoire' can help capture the unique characteristics of the teachers' environmental education curriculum, by illuminating aspects of 'building' and 'expanding' different kinds of curricular approaches and skills. In this respect, teachers' acts of prioritising, resourcing, rehearsing and practising emerged as the main themes. The focus on action also invokes a sense of 'reservoir' and 'resource' (Bernstein 1996), e.g. the 'reservoir' can be vast when it comes to knowledge of the environment. The analytic 
focus lay in the idea of repertoire as denoting a relationship between reservoir and resource, by stressing the cultural contexts that influence the ways in which particular modes of the relationship are formed. That is, while the objective boundary of reservoir might be unknown, the characteristics of teachers' participation and the surrounding conditions that circumscribe curricular development bring to the fore the cultural boundness of resources and pedagogical opportunities that shape and constrain teachers' curricular story-making. Teachers' accounts, within this study, point to three 'sites' in which ideas and action for curricular practice are initiated and circulate, and therefore form the process of pedagogical renderings of culturally available stories related to environmental and sustainability issues, as follows:

- Teachers' groups and NGOs: the major sites of professional learning, collective identity formation, and new and experimental ideas about curriculum;

- School culture and National Curriculum: the actual site of curricular practice, constraints of the timetable, examinations, subject divisions and the individualised cultures of teachers; and,

- Cultural narratives of the environment: the media, everyday consumption, environmental concerns, controversial social issues, environmental policies, etc.

Although tentative, these are meaningful locations where teachers' curricular repertoires are built and practised, operating as symbolic practices and processes; and this model of curriculum can be differentiated from other 'participatory' ones that, in my view, still presuppose the top-down approach to the curriculum and to teachers as users of the curriculum (Remillard 2005; Schwarz et al. 2007). In theoretical terms, they are the locations of teachers' 'social practices' that are constituted variously 
through discursive orders and embodiment in time- and space-bound conditions, which determine human agency (Macnaghten \& Urry, 1998). In more concrete terms, materials such as lesson plans, teaching guides and programme books represent shared concerns and meanings among the participants in the teachers' groups and NGOs, and hence form a more concrete version of possible repertoires however the relationship between the three locations can be in tension. For example, teachers may find the institutional culture in their schools hampers the actual implementation of the curriculum. Also, cultural narratives of the environment may impinge on the provision for new environmental concerns, by producing frames of interpretation through the medium of popular culture or particular cultural events, which sometimes teachers alone cannot fully address. The various curricular topics comprising teachers' repertoires seem to suggest that there are different ways in teachers' repertoire-making processes, which are mediated by the cultural processes of pedagogical rendering meanings of science, the environment and education.

For the inquiries, six curricular topics were identified as illustrative cases of teachers' main interests and concerns that characterised the environmental education of these eleven teachers: namely, alternative energy, environmental issues, health and well-being, biotechnology issues, outdoor education and green philosophy education. Importantly, the six curricular topics are neither exclusive nor exhaustive categories that consist of the eleven teachers' environmental education curricular practice. Instead, they illustrate the notion of 'repertoire' by depicting various contexts and modes that shape teachers' specialisations or personal pedagogies and topics that are related to the characteristics of environmental education enacted by the teachers - that is, those that extend the 'standard' range of curricular repertoire. In the case of the science teachers, their environment-related curricular repertoires are likely to be 
grounded in their ability to identify and select relevant resources from science-related contexts; but the scope goes beyond the mandated curricular areas such as environmental science and ecology, as June's well-being case exemplifies.

Among the six topics, some were more concerned with a teacher's unique interest and expertise (e.g. alternative energy - Han), while others were shared among the teachers. Whilst still considering that there are potential elements in the curricular narratives that might be fully developed into a form of repertoire, in particular when they are well connected into a teacher's own vision story - that is formative narrative of their personal and professional identity-making (XXXX 2008) - representing teachers' curriculum in terms of six categories was intended to stress some ways in which curricular topics and subject matters reflected temporal, cultural and historical particularities in the construction of pedagogical meaning. Table 2 summarises the story elements that consist of teachers' curricular repertoires in ways that indicate different configurations of the mechanisms of representation and relationships among the locations.

[Please insert Table 2 here.]

So, what new insight does this inquiry into repertoire generate for the discussion of teacher knowledge in science education? Most importantly, the findings suggest that the notion of repertoire should be redefined beyond the framework of certainty and mastery, as is often presumed in teacher professionalism discourses (Appleton, 2003; Scott, 2003; Smith, 1999), by taking into account contingency and complexity faced by teachers in the construction of pedagogical meaning. In the follow section, I present three curricular topics, each of which concerns particular cultural framings of environmental issues. As a repertoire, each curricular topic signifies a unique way in which different components of teacher knowledge and 


\section{Constructing curriculum repertoires : Translation from environmental stories to} pedagogies

1) Alternative energy: science education as a means of solution-seeking My work has been focused on energy issues. It happened to be like that since I was engaged in the Teachers' STS Group and NGO activities. I am (Seyoung, I am or I was?) running an alternative energy research club at the school. During the school festival, pupils prepared a booth where they demonstrated how to cook rice by using a slow cooker and presented the actual working of solar energy. (Han, H3)

'Alternative energy' was Han's unique theme, and the energy club at the school is a testament to her personal devotion. As a science (specifically an earth science) teacher, she considers teaching about alternative energy to be essential to achieving her ideal of science education that incorporates science and value issues. Han's repertoire then touched on different locations where she reflected on ideas and teaching experiences, including the university curriculum, the Teachers' STS Group, the NGO and the school. Participation in developing and teaching educational 
programmes in an NGO is not usually expected of a teacher's work, but for Han, it became a key site for professional development.

"The hands-on experience related to alternative energy can be as valuable an experience as outdoor education is. Fundamentally, it is about nurturing deep sensitivity in pupils' mindsets. In this way, it can be an alternative approach to the conventional, 'tighten-your-belt' type of energy education. Although environmental education is increasingly popular in NGOs, our programme is the unique place to learn about energy issues. The traditional approach in $\mathrm{KEMCO}^{\mathrm{iii}}$ and school education in general tends to put too much emphasis on 'saving'. In contrast, our focus lies in alternatives.” (Han, H2)

Teaching about alternative energy is not new in the National Curriculum, in that the importance and different types of alternative energy are introduced in the science syllabus; but Han's curriculum goes farther than that which is mandated in the curriculum by pursuing the value of 'hands-on' activities through which pupils can see how the alternative energy system really works, and thus learn more than abstract ideas:

"I am currently teaching about alternative energy at the NGO during the weekends. We developed and tested a solar energy programme for children through several times of evaluation, and then we are now developing a wind power energy programme as a follow-up programme. It seems to work quite well, and I can say that this is a significant achievement because of its unique focus and speciality. The next stage should be about how we can disseminate the approach so that it can be shared with more potential learners. Children seem to like to come around here, probably because the educators are not too strict, and learning is not as demanding as it is at the schools. This programme 
can be re-packaged as a type of so-called 'early education' in the sense (that) it can contribute to nurturing citizenship skills for environmental responsibility as a future consumer, which begins with the use of renewable energies in their life contexts. It strategically aims to appeal to a wider range of the parents including the ones who are not probably that much environmentally conscious, but simply interested in 'gifted education'. They would think that the programme serves this interest through hands-on learning of 'high-technology'.” (Han, H3)

Han's narrative of her repertoire comprised detailed accounts of the process of developing energy education programmes in the NGO. She was well aware of what may appeal to children and parents. The popular discourses such as "early education" and "gifted education" were drawn upon to provide justification for the educational value of alternative energy education. Interestingly, when she made claims about how the programme can contribute to early education in terms of "citizenship skills", the original meaning, that is usually associated with parents' obsession with their child's academic talent, was twisted. The same rhetoric was applied to "gifted education" and "high-technology".

Han's belief in alternative energy as an effective learning approach was based on her long experience of, and commitment to alternative approaches to science teaching, in and outside the school and the curriculum, as was often the case in the teachers' professional development opportunities in this study. With fifteen years' teaching experience, Han's repertoires were more extensive than those of any other teacher in the study, but it was when she was talking about alternative energy that her voice was most full of conviction and passion. Indeed, working with academics and NGO people on energy issues and STS-related issues in general, "convinced" her to 
argue that there can be an "answer" to environmental problems, which concurs with her disposition of "progressivism" - the central theme running through her life story. This strong sense of conviction appears to be a unique case among teachers' repertoires, as other curriculum narratives display more uncertainty about pedagogical skills and knowledge, and teachers' struggles in transferring environmental topics into educational language.

Yet still Han often felt confused about the degree of "expertise" that teachers need to have. In fact, NGO activities were largely run by policy researchers who are the thinkers, and education programmes tended to be treated as mere projects. As Han noticed that education is only considered to be a minor role in the work of the NGOs, the value of education and teachers' knowledge and professionalism appear to be far from fully appreciated or firmly established in actual practice. Han's repertoire of alternative energy then was being practised and re-written through an ongoing effort to consolidate the educational significance and meaning of the curriculum in the NGO and the school.

2) Environmental decision-making: limits of science in the real issue context

The pedagogical concern over the decision-making approach to environmental issues represents a typical case in which curriculum repertoires do not feature teachers' knowledge and competence in a straightforward way. For these Korean teachers, the stress on decision in the teachers' repertoires for environmental issues was related to the actual context of environmental policy and social processes, where the extreme division between the 'conservation' side and the 'development' side often appears, but how this instructional framework actually helps to facilitate pupils' learning is another matter. 
"Even though I try to approach environmental issues from the so-called 'Two Hats' perspective (Hug, 1977), it doesn't work like that from pupils' perspectives. At the stage of the final decision making after all these debates, pupils seem to try to read my face as if I've got my own preference. Then they say, "I know you are giving me a bad score if I vote for the 'development' side!”. I mean, pupils already see me as an environmentalist even though I try hard to remain impartial. It seems that more considerations are needed." (Yun) Indeed, although it might be an easy approach to decision-making, it was not sufficient to facilitate pupils' learning in that pupils already presumed the 'right answer' without critical engagement with their own ideas.

"When teaching environmental issues, I focus more on pupils' decisionmaking processes than knowledge acquisition. The know-how is to set the basic rules that every pupil should follow. For instance, everybody should participate in the discussion, and clarify their own ideas through any forms of presentation. In this, the teacher should prepare as many available resources as possible so that pupils can examine diverse perspectives as well as their own. We (STS Teacher Group) developed a consensus conference model to teach the Reclamation Project ${ }^{\text {iv }}$ issue. In the first stage, pupils choose to be one member of the ecosystem including for example, seashells, and put on a mask that stands for the creature. In this process, they are encouraged to ponder the values and perspectives from the standpoint of the various members of the ecosystem, and represent their points of view through good argumentation. At this point, the teacher shouldn't impose any ideas. Then, they vote to decide whether the reclamation project should proceed. The result can be either proor anti- the project, and pupils do not necessarily favour the environmentalist 
position. I am caught in a dilemma when the majority of them vote for 'development'. I thought, "I've done enough to encourage them to think carefully" however in fact, they seem to make a decision too easily, or tend to take a very neutral position, not bothering to engage critically." (Han, H2)

Han's consensus conference model $^{\mathrm{v}}$ aimed to engage pupils in thinking beyond human-centred views by considering what animals would think about the environmental changes that the Reclamation Project could cause; but the story's ending still depended on the pupils' decisions. While there are different opinions about teacher neutrality, Han and Yun seemed to share the view that the main objective of instruction should be to develop pupils' critical thinking skills. Both Han and Yun, however, found it difficult to engage pupils in the learning process itself, as pupils regarded the outcome of the decision as the main focus. Then their concern was to find out the reasons for the barriers that obstruct pupils' engagement in environmental issues. The problem of the conventional learning attitude was frequently addressed as more of a universal problem prevailing in Korean schools in which pupils are more used to giving the 'right' answer than expressing their own ideas and taking part in the discussion. For teachers, it is not easy to overcome this problem since pupils actually need this style of so-called 'spoon-fed' (the same expression in Korean) teaching, given the overloaded learning objectives and fiercely competitive exam-centred culture. Kang (2006) also identifies this tension as a prominent pedagogic process in classroom interaction, in explaining why a geography teacher - the study's key informant - should opt out of environment-related contents that she apparently wanted to introduce; but then the teachers wanted to know what pupils think about environmental issues more generally: 


\begin{abstract}
"Generally pupils seem to approve of the ideas, such as protection or conservation, without critical deliberation. The truth might be that they are not so interested in this kind of stuff, always occupied with the incessant (work)loads of study that even continue after school, but I do wonder whether this sort of pro-environmental disposition comes from their relatively affluent background in this region. I want to understand, if only vaguely, what this young generation thinks about their environment." (Lee, L3)
\end{abstract}

“I wonder whether the pupils' dispositions come already oriented toward conforming to economic ideologies, as pupils are brought up in a society where economic values outweigh anything else. Also, it might be related to their less affluent living conditions in this area, that push children to adopt the view that being an economically well-off person is the (only) desirable future." (Han, H1)

The observations made by Lee and Han suggest that both teachers see pupils' economic backgrounds as influential in forming their environmental dispositions. Pupils' living situations and experiences can be formative to some degree, if not the only, or definitive factor. Teachers' understanding of 'larger contexts' such as this might trigger further reflections on simple decision-making approaches in ways that reflect pupils' multiple identities and complex living situations.

To sum up, teachers' reflections on the limit of decision-making methods in teaching about environmental issues illuminate the need for understanding complexity, controversy and political situations involved in the social processes of environmentrelated decision-making, and the potential influences on pupils' preconceptions about environmental issues. 
3) Health and 'well-being' : science as critical inquiry

As mentioned earlier, the well-being phenomenon was a good subject matter to make use of scientific information and inquiry methods to address health issues. June was able to conceptualise "consumer education" in her own words.

"I am interested in consumer education that integrates environmental issues.

There are no obvious answers when it comes to consumption. Some people would prioritise environmental values, whilst others put their own tastes or health at the top of the list. I want to see how pupils communicate with each other to make a decision by considering conflicting values such as these. It is said that behaviour change is the ultimate goal of environmental education however, pupils' action is very limited for making big changes, but any kind of behaviour is somehow related to consumption. This is why I think consumer education is very important." (June, J1)

“I developed a lesson called, 'What will I buy for a snack?'. The lesson begins with pupils' talking about their experiences of buying snacks after school. Then, the next step is to re-construct their story by considering health issues such as the concept of the 'life-cycle' of the food that they selected to buy. So, the gist of this activity is not merely about making a right decision, instead, it aims to put pupils in a conflicting situation so that they can engage in 'rational communication'.” (June, J1)

In the previous section, the teachers' repertoires of environmental issues were also based on learning objectives that encourage pupils to understand different values and perspectives related to the environment and to enhance their communication skills by 
engaging in decision-making processes, but what is distinguishable in June's consumer education is the emphasis on pupils' everyday life contexts. The idea of decision-making should be relevant to them and the decision should have a direct impact on their behaviour:

"I would tell pupils not to eat junk food because it is not healthy, however, the dilemma is that when pupils want to buy some snacks at school, for example, the choice will be limited by their pocket money. So, I need to say more than healthy and unhealthy stuff. Furthermore, we can't always put the environmental value as the top priority in every single matter. People have their own tastes that may come against environmental values. If too much emphasis is placed on the environment, pupils may end up with a negative perception about it, or complain that we can't do anything because of the environment. We can't help but to make a compromise at some point." (June, J1)

In this vignette, June deliberates on how pupils might think about the 'environment' if environmental values are imposed as a moral duty that pushes them to act 'for' the environment. She knew from her own experiences that people could just act for the environment only because it is the right thing to do. Buying organic food was a very personal lifestyle action that presented June with a dilemma, and she was knowledgeable as to which items were organic and which were not, given all the options and qualities. Confessing that if she always put environment as her top priority it would be so stressful, June believed that pupils would feel the same way, and therefore the pedagogic focus should lay on the learning process itself. This perspective then distanced June from some of the other teachers' partisan or campaigning styles, which she regarded as "pedagogically unsound". 
"Here is the case. There have been many organic goods imported from Australia lately. It is organic but it involves extra cost and energy in the transportation and packaging. This is where my question starts, but those teachers seem to assume that there is such an environmental value out there, therefore, what we need to do is to act for it." (June, J2)

In this, June's focus was on asking the question as to what is of environmental value before considering acting upon it, and this is the very core question that June expected her pupils to be able to wrestle with through learning about science. Her repertoires then included trendy snacks such as "well-being milk" and "black bean milk" by encouraging pupils to see through the images attached to 'environmental' or 'healthy' labels and to be motivated to seek and know the "truth". "Scepticism" then is a very "scientific attitude" that should be promoted in science education. In this way, June's repertoire for consumer education was closely related to the ideals of science for citizenship and the scientific literacy movement (e.g. Irwin, 1995). Other science teachers also addressed the need to reformulate the role of science and scientific knowledge for investigating the truth behind popular images and commercial goods.

“There are popular delusions or misconceptions about scientific knowledge.

'Citizen Science' is the idea that ordinary people can do science. There was an actual case of this: local housewives set out to investigate air pollution and succeeded in disclosing the fact that it was caused by the overproduction of dioxin produced by the local incinerator." (Kim, K1)

Kim's story went farther on his observations of the ways in which science was used to promote commercial goods such as vitamin-enriched food and how susceptible people were to advertisements. Indeed, from the perspective of a science teacher, cultural phenomena and narratives appeared to provide many topics and issues to be critically 
examined through science and about science. In this way, teachers' reflections on their own life styles and actions, together with their observations on cultural phenomena, seem to meet theoretical perspectives and concepts, in ways that lend themselves to supporting teachers in reflexive teaching and learning processes. In this regard, cultural phenomena and trends related to health and well-being became culturally available resources as well as increasing the challenges for teachers to teach science. How can teachers then approach the truth about the role and contribution of science? As June stressed, the pedagogical significance may emerge as teachers extend their repertoires by helping pupils wrestle with issues, deconstructing and reconstructing meanings concerning ideas of 'science', 'health', 'well-being' and 'environment'.

In summary, Han's alternative energy repertoire seems to show the extent to which an experienced teacher's professionalism is actualised through concrete curricular approaches and models. Indeed, teaching about alternative energy was a personally pursued "answer" as a science teacher who is committed to environmental education. In contrast, the other topics illustrate more contingency and complexity in developing and practising the curriculum. In the environmental issues repertoire, the teachers' main pedagogic concerns were to enhance pupils' decision-making skills through critical engagement with issues. Nevertheless teachers found learning through real cases was not always successful, and their further deliberations discovered the importance of individual pupils' life contexts and actual policy contexts that might impinge on pupils' preconceptions about environmental issues and their attitudes to learning about them. The health and 'well-being' repertoire was directly concerned with the environmental issues repertoire in terms of its focus on pupils' everyday life experiences. For science teachers, addressing everyday life issues led to a reflexive attitude towards the role of science, in setting the pedagogical aim of knowing the 
truth 'about' science, and/or 'through' science by deconstructing the messages conveyed through cultural trends and reconstructing possible educative values.

\section{Implications for research and practice: Teacher repertoire in wider contexts}

In the teachers' narratives, their sense of competency and agency was indeed subject to cultural conditions and dynamics, in which the individual teachers (can find themselves being forced to) examine their beliefs and knowledge. Curricular repertoires are then comprised by ongoing, reflexive activities of translating meanings in cultural texts and (re-)constructing pedagogic text. The empirical evidence in this study shows that as a result, teachers developed a more critical attitude toward the nature of knowledge and the knowing process. For these teachers then, developing curricular repertoires required the ability to deal with contingency and complexity, as often observed in teachers' struggles in comprehending meanings, in particular when idioms such as 'well-being' become the taken-for-granted guide for environmental action, which are aggravated by the fact that the 'truth' about stories is not always knowable or easily accessible. This means that a shift away from the scientific objectivism and naïve realism that have underpinned modern science education as a means for seeking 'certainty' as a desirable pedagogical outcome is indeed necessary (Fendler \& Tuckey, 2006). Important to emphasise here is the co-existence of, and interplay between, two approaches/attitudes that the study found in teachers' conceptions about science - scepticism 'about' science, and scepticism 'through' science. The former refers to science and scientific practice as intertwined with sociopolitical processes, and the latter as generating facts/truths. To science educators and researchers who increasingly face the need to address environmental issues, this dual conception about science suggests that the aims of science learning should be defined 
beyond the deficit model in knowledge and understanding. For example, the recent social imperative on how to respond to global warming and climate change has become the critical topic that should also be considered by education. The tendency in science education, however, still seems to reinforce the role of science as guiding human action by assuming a rather linear relationship between the causes and effects of global warming, and the subsequent environmental issues and behaviour change (Shepardson et al., 2009). While still acknowledging that scientific findings and consensus is necessary means to inform our knowledge and understanding, what might be complementary to this is a critical attitude about science that examines the socio-political sense-making processes through which such knowledge and consensus become 'the' understanding that guides human action.

This study focused attention only on teachers' viewpoints and sense-making processes by highlighting the role of teacher motivation in stimulating the development of new repertoires, therefore offered a limited account on the pedagogic process that is incomplete without pupil participation. As the teachers in this study mentioned, children also bring to school their preconceptions and positions relating to environmental issues which are more complex than scientifically defined concepts (e.g. on children's concept of healthy/unhealthy, see Reeve \& Bell, 2009). Triangulating the empirical data on pupils and other social processes involved in pupils' conceptions about what is an issue and what is worth learning will provide a more holistic picture of what repertoires are developing and what should be developed for science education.

\section{References}

Agelidou, E., \& Flogaitis, E. (2003). Kindergarten teachers' conceptions about nature 
and the environment. Environmental Education Research, 9(4), 461-478.

Appleton, K. (2003). How do beginning primary school teachers cope with science? Toward an understanding of science teaching practice. Research in Science Education, $33,1-25$.

Atkinson, R. (2002). The life story interview. In J. F. Gubrium \& J. A. Holstein (Eds.), Handbook of interview research: Context \& method (pp.121-140). Thousand Oaks, Calif:: Sage Publications.

Barone, T. (1997). Among the chosen: A collaborative educational (auto)biography. Qualitative Inquiry, 3(2), 222-236.

Barrett, M.J. (2008). Participatory pedagogy in environmental education: Reproduction or disruption? In A. Reid, B.B. Jensen, J. Nikel, \& V. Simovska (Eds)., Participation and learning: Perspectives on education and the environment, health and sustainability (pp.212-24). New York: Springer.

Bernstein, B. (1996). Pedagogy, symbolic control and identity: Theory, research, critique. London: Taylor \& Francis.

Brockmeier, J., \& Harré, R. (2001). Narrative: problems and promises of an alternative paradigm. In J. Brockmeier, \& D. A. Carbaugh (Eds.), Narrative and identity: Studies in autobiography, self, and culture (pp.39-58). Studies in narrative, v. 1. Amsterdam: John Benjamins.

Bruner, J. (1991). The narrative construction of reality. Critical Inquiry, 17, 1-21.

Bryce, T. (2004). Tough acts to follow: The challenges to science teachers presented by biotechnological progress. International Journal of Science Education, 26(6), 717733. 
Carter, K. (1994). Preservice teachers' well-remembered events and the acquisition of event-structured knowledge. Journal of Curriculum Studies, 26(3), 235-252.

Carter, L. (2008). Sociocultural influences on science education: innovation for contemporary times. Science Education, 92(1), 165-181.

Chase, S. E. (2005). Narrative inquiry: Multiple lenses, approaches, voices. In N. K. Denzin, \& Y. S. Lincoln (Eds.), The Sage Handbook of qualitative research, 3rd edn. (pp.651-679). Thousand Oaks, Calif.; London: Sage.

Colucci-Gray, L., Camino, E., Barbiero, G. \& Gray, D. (2006). From scientific literacy to sustainability literacy: An ecological framework for education. Science Education, $90(2), 227-252$.

Cook, V. (2008). The field as a 'pedagogical resource'? A critical analysis of students' affective engagement with the field environment, Environmental Education Research, $14(5), 507-517$.

Corney, G., \& Reid, A. (2007). Student teachers' learning about subject matter and pedagogy in education for sustainable development. Environmental Education Research, 13(1), 33-54.

Cotton, D. R. E. (2006). Implementing curriculum guidance on environmental education: the importance of teachers' beliefs. Journal of Curriculum Studies, 38(1), $67-83$.

Elbaz, F. (1991). Research on teacher's knowledge: The evolution of a discourse. Journal of Curriculum Studies, 23(1), 1-19.

Elbaz-Luwisch, F. (2007). Studying teachers' lives and experience: Narrative inquiry into K-12 teaching. In D. J. Clandinin (Ed.), Handbook of narrative inquiry: Mapping a methodology (pp.357-382). Thousand Oaks, Calif.; London: SAGE. 
Fendler, L., \& Tuckey, S. F. (2006). Whose literacy? Discursive constructions of life and objectivity. Educational Philosophy and Theory, 38(5), 589-606.

Gough, N. (1999). Rethinking the Subject: (de)constructing human agency in environmental education research. Environmental Education Research, 5(1), 35-48.

Gough, N. (2002). Thinking/acting locally/globally: Western science and environmental education in a global knowledge economy. International Journal of Science Education, 24(11), 1217-1237.

Gudmundsdottir, S. (1991). Story-maker, story-teller: Narrative structures in curriculum. Journal of Curriculum Studies, 23(3), 207-218.

Hart, P. (1996). Problematizing enquiry in environmental education: Issues of method in a study of teacher thinking and practice. Canadian Journal of Environmental Education, 1, 56-88.

Hart, P. (2003). Teachers' thinking in environmental education: Consciousness and responsibility. New York: Peter Lang Publishing.

Hart, P. (2008). Elusive participation: methodological challenges in researching teaching and participatory learning in environmental education. In A. Reid, B. B. Jensen, J. Nikel \& V. Simovska (Eds.), Participation and learning: perspectives on education and the environment, health and sustainability (pp.225-240). New York: Springer.

Hart, P., \& Nolan, K. (1999). A critical analysis of research in environmental education. Studies in Science Education, 34, 1-69.

Hug, J. (1977). A report on the North American Regional Seminar on Environmental Education: a confrontation with the issues. Environmental education for the real world. Columbus, OH: CSMEE Information Center. 
Irwin, A. (1995). Citizen science: A study of people, expertise and sustainable development. London; New York: Routledge.

Jiménez-Alexiandre, M., \& Pereiro-Muñoz, C. (2002). Knowledge producers or knowledge consumers? Argumentation and decision making about environmental management. International Journal of Science Education, 24, 1171-1190.

Kang, J. (2006). (A) Qualitative case study on the geography teacher's environmental education in a Korean high school classroom. Unpublished PhD thesis, Seoul: Seoul National University.

Kolstø, S. D. (2001). Scientific literacy for citizenship: Tools for dealing with the science dimension of controversial socioscientific issues. Science Education, 85, 291310.

Kuhn, T. S. (1962). The structure of scientific revolutions. Chicago: University of Chicago Press.

Loughland, T., Reid, A., \& Petocz, P. (2002). Young people's conceptions of environment: a phenomenographic analysis. Environmental Education Research, 8(2), 187-197.

Macnaghten, P., \& Urry, J. (1998). Contested Natures. London: Sage.

Michael, M., Grinyer, A., \& Turner, J. (1997). Teaching biotechnology: identity in the context of ignorance and knowledgeability. Public Understanding of Science, 6, 1-17.

Midgley, M. (1992). Science as salvation: A modern myth and its meaning. London: Routledge.

Mishler, E. G. (1986). Research interviewing: Context and narrative. Cambridge, Mass: Harvard University Press. 
Nowotny, H., Scott, P., \& Gibbons, M. (2001). Re-thinking science: Knowledge and the public in an age of uncertainty. Polity Press: Cambridge.

Oulton, C., Dillon, J., \& Grace, M. M. (2004). Reconceptualizing the teaching of controversial issues. International Journal of Science Education, 26(4), 411-423.

Payne, P. G. (2005). Lifeworld and textualism: Reassembling the researcher/ed and 'others'. Environmental Education Research, 11(4), 413-431.

Reeve, S., \& Bell, P. (2009). Children's self-documentation and understanding of the concepts 'Healthy' and 'Unhealthy'. International Journal of Science Education, 31(14), 1953-1974

Reid, A., \& Scott, W. (2006). Researching education and the environment: Retrospect and prospect. Environmental Education Research, 12(3-4), 571-587.

Remillard, J. T. (2005). Examining key concepts in research on teachers' use of mathematics curricula. Review of Educational Research, 75(2), 211 - 246.

Riessman, C. K. (2003). Analysis of personal narratives. In J. F. Gubrium \& J. A. Holstein (Eds.), Postmodern interviewing (pp. 331-347). London: Sage.

Schwarz, C. V., Gunckel, K. L., Smith, E. L., Covitt, B. A., Bae, M., Enfield, M., \& Tsurusaki, B. K. (2007). Helping elementary preservice teachers learn to use curriculum materials for effective science teaching. Science Education, 92(2), 345377.

Scott, S. (2003). Innovative use of teaching repertoire: A study in transfer of complex strategies into classroom practice by novice teachers. European Journal of Teacher Education, 26(3), $365-377$. 
Shepardson, D. P., Niyogi, D., Choi, S., \& Charusombat, U. (2009). Seventh grade students' conceptions of global warming and climate change. Environmental Education Research, 15(5), 549-570.

Smith, R. G. (1999). Piecing it together: student teachers building their repertoires in primary science. Teaching and Teacher Education, 15, 301-314.

Solomon, S., Qin, D., Manning, M., Chen, Z., Marquis, M., Averyt, K.B., Tignor, M., \& Miller, H. L. (Eds.). Contribution of Working Group I to the Fourth Assessment Report of the Intergovernmental Panel on Climate Change. United Kingdom and New York, NY, USA, Cambridge University Press, Cambridge, UNESCO-UNEP (1978). The Tbilisi Declaration. Connect, III(1), 1-8.

Whitehouse, H. (2001). 'Not greenies' at school: Investigating the discourses of environmental activism in regional Australia. Australian Journal of Environmental Education, 17, 71-76.

Weinstein, M. (2006). Slash writers and guinea pigs as models for a scientific multiliteracy. Educational Philosophy and Theory, 38(5), 607-623.

Zeidler, D. L., Sadler, T. D., Simmons, M. L., \& Howes, E. V. (2005). Beyond STS: A research-based framework for socioscientific issues education. Science Education, 89(3), 357-377.

XXXX (2008). Teachers' stories of environmental education: Blurred boundaries of professionalism, identity and curriculum. Unpublished Ph.D thesis. Bath: University of Bath.

XXXX (2009). Teachers' environmental education as creating cracks and ruptures in school education: A narrative inquiry and an analysis of teacher rhetoric. Environmental Education Research, 15(6), 697-714. 
XXXX (2010, in press). Rethinking the contribution of science education for addressing environmental issues: A literature review. Journal for the Korean Society of Biology Education, 38(1).

${ }^{\mathrm{i}}$ For further discussion on the genre of environmental education, see Canadian Journal of Environmental Education 2002, 7(2); Environmental Education Research 2007, 13(2).

${ }^{\text {ii }}$ For critical review of SLE concept, see Environmental Education Research, 1998, $9(8)$

${ }^{\text {iii }}$ Korea Energy Management Corporation (http://www.kemco.or.kr/english/index.asp)

iv Saemangum reclamation project was the biggest national development project in the 1990s and brought about severe resistance from environmentalist groups. A brief account: As one of the five biggest tidal flats in the world, preservation of the Saemangeum area has become a concern that extends beyond the borders of Korea. Over $50 \%$ of birds migrating between New Zealand and Siberia are estimated to rest on the tidal flat. The area is located along the southwestern shore of the Korean peninsula in the North Cholla Province. It is the main livelihood for most of the surrounding fishing community (Source: http://www.greenkorea.org).

${ }^{\mathrm{v}} \mathrm{A}$ consensus conference is defined as follows: a forum at which a citizens' panel, selected from members of the public, questions 'experts' (or 'witnesses') on a particular topic, assesses the responses, discusses the issues raised and reports its conclusions at a press conference (UK CEED; http://www.ukceed.org). The model first began in Denmark in the late 1980s, and such conferences have been held in many countries since then, including Korea. 
Table 1. Teacher Profiles

\begin{tabular}{|c|c|c|c|}
\hline $\begin{array}{l}\text { Name } \\
\text { (Gender, } \\
\text { Teaching } \\
\text { years) }\end{array}$ & Subject & Main areas of interest & Affiliation \\
\hline $\begin{array}{l}\text { Han } \\
\text { (Female, } \\
\text { 15yrs) }\end{array}$ & $\begin{array}{l}\text { Science/earth } \\
\text { science }\end{array}$ & $\begin{array}{l}\text { Alternative energy, } \\
\text { value issues in } \\
\text { science, } \\
\text { NGO activities }\end{array}$ & $\begin{array}{l}\text { Korean Teachers \& } \\
\text { Educational Workers' Union } \\
\text { Teacher's STS Group, } \\
\text { Centre for Energy Alternative }\end{array}$ \\
\hline $\begin{array}{l}\text { Lee } \\
\text { (Male, 11yrs) }\end{array}$ & Science/biology & $\begin{array}{l}\text { 'Wellbeing' and } \\
\text { health, } \\
\text { ecological thinking }\end{array}$ & $\begin{array}{l}\text { Korean Teachers \& } \\
\text { Educational Workers' Union, } \\
\text { Korean Teacher's } \\
\text { Organization For Ecological } \\
\text { Education And Activity }\end{array}$ \\
\hline $\begin{array}{l}\text { June } \\
\text { (Female, } \\
\text { 14yrs) }\end{array}$ & Science/physics & $\begin{array}{l}\text { Issue-based science } \\
\text { teaching, } \\
\text { 'well-being' and } \\
\text { health }\end{array}$ & N/A \\
\hline $\begin{array}{l}\text { Kim (Male, } \\
\text { 16yrs) }\end{array}$ & $\begin{array}{l}\text { Science/earth } \\
\text { science }\end{array}$ & $\begin{array}{l}\text { Issue-based science } \\
\text { teaching, } \\
\text { green education } \\
\text { philosophy }\end{array}$ & $\begin{array}{l}\text { Korean Teacher's } \\
\text { Organization For Ecological } \\
\text { Education And Activity }\end{array}$ \\
\hline $\begin{array}{l}\text { Young } \\
\text { (Female, 6rs) }\end{array}$ & Science/biology & $\begin{array}{l}\text { value issues in } \\
\text { science }\end{array}$ & Teachers' STS Group \\
\hline Min & Art & Outdoor education, & Korean Teachers \& \\
\hline
\end{tabular}




\begin{tabular}{|c|c|c|c|}
\hline $\begin{array}{l}\text { (Male, } \\
17 \mathrm{yrs})\end{array}$ & & $\begin{array}{l}\text { art-based ecological } \\
\text { curriculum, } \\
\text { ecological thinking }\end{array}$ & $\begin{array}{l}\text { Educational Workers' Union, } \\
\text { Korean Teacher's } \\
\text { Organization For Ecological } \\
\text { Education And Activity }\end{array}$ \\
\hline $\begin{array}{l}\text { Hong } \\
\text { (Male, } \\
\text { 24yrs) }\end{array}$ & History & $\begin{array}{l}\text { Outdoor education, } \\
\text { NGO activities }\end{array}$ & Korea Youth Union \\
\hline $\begin{array}{l}\text { Nam } \\
\text { (Male, 3yrs) }\end{array}$ & Environment & $\begin{array}{l}\text { General issues in } \\
\text { environmental } \\
\text { education }\end{array}$ & $\begin{array}{l}\text { Korean Environmental } \\
\text { Education Teachers' Group }\end{array}$ \\
\hline $\begin{array}{l}\text { Sue (Female, } \\
\text { 2yrs) }\end{array}$ & Environment & $\begin{array}{l}\text { General issues in } \\
\text { environmental } \\
\text { education }\end{array}$ & $\begin{array}{l}\text { Korean Environmental } \\
\text { Education Teachers' Group }\end{array}$ \\
\hline $\begin{array}{l}\text { Hee } \\
\text { (Female, } \\
\text { 2yrs) }\end{array}$ & Environment & $\begin{array}{l}\text { General issues in } \\
\text { environmental } \\
\text { education }\end{array}$ & $\begin{array}{l}\text { Korean Environmental } \\
\text { Education Teachers' Group }\end{array}$ \\
\hline $\begin{array}{l}\text { Yun (Female, } \\
\text { 2yrs) }\end{array}$ & Environment & $\begin{array}{l}\text { General issues in } \\
\text { environmental } \\
\text { education }\end{array}$ & $\begin{array}{l}\text { Korean Environmental } \\
\text { Education Teachers' Group }\end{array}$ \\
\hline
\end{tabular}

Table 2. Story elements of curricular repertoires

\begin{tabular}{|l|l|l|l|}
\hline Curricular topics & Teachers' Groups and & School culture and & Cultural narratives \\
NGOs & National Curriculum & of the environment \\
\hline Alternative energy: & $\begin{array}{l}\text { Programme } \\
\text { development }\end{array}$ & Energy club, & Energy crisis, \\
hands-on activities & solution, global \\
\hline
\end{tabular}




\begin{tabular}{|c|c|c|c|}
\hline & $\begin{array}{l}\text { experience in an } \\
\text { NGO (Han) }\end{array}$ & & scale \\
\hline $\begin{array}{l}\text { Environmental } \\
\text { issues: }\end{array}$ & $\begin{array}{l}\text { Teaching guides and } \\
\text { materials by } \\
\text { Teachers' STS Group } \\
\text { and EE Group (all } \\
\text { science teachers) }\end{array}$ & $\begin{array}{l}\text { Decision-making } \\
\text { focused instruction, } \\
\text { teacher neutrality }\end{array}$ & $\begin{array}{l}\text { Conservation side } \\
\text { vs. development } \\
\text { side opposition in } \\
\text { policy cases }\end{array}$ \\
\hline $\begin{array}{l}\text { Health and 'well- } \\
\text { being': }\end{array}$ & $\gamma$ & $\begin{array}{l}\text { School dinner and } \\
\text { garden }\end{array}$ & $\begin{array}{l}\text { Consumption and } \\
\text { commercial trends }\end{array}$ \\
\hline $\begin{array}{l}\text { Biotechnology } \\
\text { issues: }\end{array}$ & $\begin{array}{l}\text { Teachers' STS Group } \\
\text { (Han, Young) }\end{array}$ & $\begin{array}{l}\text { (Science) teachers' } \\
\text { silence }\end{array}$ & $\begin{array}{l}\text { Stem cell research } \\
\text { scandal }\end{array}$ \\
\hline Outdoor education: & $\begin{array}{l}\text { Teachers' EE Group } \\
\text { (Min), } \\
\text { Youth Union (Hong) }\end{array}$ & $\begin{array}{l}\text { The limit of time and } \\
\text { space }\end{array}$ & $\begin{array}{l}\text { Appreciation of } \\
\text { nature experience }\end{array}$ \\
\hline Green education: & $\begin{array}{l}\text { Teachers' } \\
\text { (Kim) }\end{array}$ & $\begin{array}{l}\text { The culture of } \\
\text { teachers, } \\
\text { the structure of the } \\
\text { National Curriculum }\end{array}$ & \\
\hline
\end{tabular}

